\title{
Respatialising the Body: The Ontologically In-between Subject in Orlan's Body of Work
}

\author{
Burcu Baykan
}

\begin{abstract}
This chapter explores the respatialisation of the embodied experience of space through the French multimedia and performance artist Orlan's body and identity altering practices. By primarily focusing on the artist's multifaceted surgery-performance series, The Reincarnation of Saint Orlan (1990-1993) and her subsequent series of digital self-portraits, Self-Hybridizations (1998-2007), this chapter traces the complex relationships between the human and the non-human domains that appear in her work, as well as the mutating, in-between bodily space that is configured within these meetings and crossovers. Thus, the main intent of this chapter is to engage with and explore these dynamic, unstable and transient states of being that Orlan's work reflects; the metamorphic, in-between areas related to the understanding of self in ontological, philosophical and artistic sense. The investigation undertaken here for this purpose primarily draws on Deleuze and Guattari's formulation of the body through their theory of becoming-other.
\end{abstract}

\section{Introduction}

This chapter creates a shift in terrain by turning from literature to performance art. As such, it delves into the respatialisation of the embodied self through the French performance and multimedia artist Orlan's body and identity altering practices. Drawing upon Gilles Deleuze and Félix Guattari's concept of becoming-other ${ }^{1}$ and its inherent set of vocabularies as a critical lens, this study explores a series of corporeal respatialisations, through which

1 Gilles Deleuze and Félix Guattari, A Thousand Plateaus: Capitalism and Schizophrenia, trans. Brian Massumi (Minneapolis and London: University of Minnesota Press, 1987). Gilles Deleuze (1925-1995) is a prolific French cultural theorist in the canon of continental philosophy who has also co-authored with French psychoanalyst and political activist Félix Guattari (1930-1992). 
the human body continually transforms beyond itself in Orlan's interdisciplinary visual art practice. This results in an investigation of two of the major projects by the artist, The Reincarnation of Saint Orlan (1990-1993) and SelfHybridizations (1998-2007). Mutative reconfigurations of the body - whether on actual physical level or through digital image technologies - are fundamental to these artistic projects. It is in this respect that Orlan's explorations into the reconceptualisation of the embodied experience of space allude to the reconsideration of corporeal possibilities and potentials by the drug trope in female literature, as it is discussed by Nycole Prowse in the opening chapter of this volume.

By primarily focusing on the artist's multifaceted surgery-performance series, The Reincarnation of Saint Orlan and her subsequent series of digital selfportraits, Self-Hybridizations, this chapter traces the complex convergences of human and non-human technological constructs, as well as the mutating, inbetween bodily space that is configured within these meetings and crossovers. Examining the corporeal interventions explored by Orlan, the main intent of this chapter is to investigate how organic human and inorganic technics are put into contact with each other and the impact of these entangling processes on the creation of in-between spaces - the dynamic, metamorphic and unstable areas related to the understanding of self in an ontological, philosophical and artistic sense. It is in this way that, the analysis pursued here is in resonance with Katsuhiko Muramoto's discussion of Teturo Watsuji's 'ethics of in-betweeness' in this volume, ${ }^{2}$ as well as this section's general examination of the 'interconnectedness' of the technologies of body, space and nature. For the investigation undertaken in this chapter, I develop a model of the body primarily through Deleuze and Guattari's notion of becoming-other. The chapter also includes their concept of intermezzo as related to the theory of becoming-other in order to consider Orlan's corporeal reconceptualisation that engenders proliferating connections and non-dualistic forms of bodily space that are no longer based on binary divisions. As such, this chapter is an attempt to elaborate the significance of Orlan's multi-media practices along the lines of Deleuze-Guattarian theory, as well as to explore the points of overlap and resonances between their projects. The current chapter, therefore, extends some of the notions and arguments explored in Chapter 1, where Prowse discussed some of the significant ways in which drugs might impact on and collapse the spatio-corporeal boundaries in literature, and provide a ground where alternative possibilities for the embodied subject can be opened up, via

2 Katsuhiko Muramoto, 'In Search of a Relational Body: Reflections on Sustainable Architecture,' in this volume. 
a Deleuze-Guattarian discussion on the body and their notion of Body without Organs. But, before plunging into such an analysis, the chapter first briefly describes the art projects that are the focus of this chapter and verbally visualise the elaborate projects Orlan constructs. It then moves on to discuss the implications of the diverse interpenetrating relationships between various human, non-human and technological parts that appear in her works for the comprehension of bodily transformations and alterations.

\section{The Reincarnation of St. Orlan}

Beyond her early work, The Reincarnation of St. Orlan is probably the most recognised and extensive project Orlan has undertaken, in which she performed while a cosmetic surgeon operated on her. In this controversial series, where the operating room became her performance space and her own flesh the artistic material, Orlan employed cosmetic surgery for the first time as an art form ${ }^{3}$ and underwent a series of nine surgeries to achieve a comprehensive self-transformation. In that sense, she continued to explore the themes present in her ouevre from the onset of her career - the themes of femininity, beauty, renewal and identity change - and use her body to provoke public reaction and debate. Regarding her utilisation of her own corporeality throughout her practice, which takes the form of performances, multi-media installations and photographic pieces, Orlan comments as follows: 'I have always regarded my female body, my artist's body as a particularly suitable material for the production of my work. ${ }^{4}$

As a multi-media conceptual project consisting of performance art, medicine, biotechnology, prosthetic technologies, communications media, filming and broadcasting, all of the surgery-performances that comprise The Reincarnation of St. Orlan were part of public display and carefully designed and choreographed by the artist. Orlan chose to remain conscious under local anaesthesia since her conscious participation was essential to choreographing and performing during the operations, ${ }^{5}$ which involved interactive communication with an international audience in art galleries around the globe. Her performance space, which she called operating-theatre, had a carnivalesque

3 Orlan, 'Intervention,' The Ends of Performance, ed. Peggy Phelan and Jill Lane (New York and London: NYU Press, 1998), 324.

4 Orlan, qtd. in Anja Zimmermann, “Sorry for Having to Make You Suffer": Body, Spectator, and the Gaze in the Performances of Yves Klein, Gina Pane, and Orlan,' Discourse 24.3 (2002): 28.

5 Kate Ince, Orlan: Millennial Female (Oxford and New York: Berg Publishers, 200o), 63. 
atmosphere. It involved the use of opulent sets and decoration, music, designer costumes worn by Orlan and the surgeons, combined with background dance-performances and multimedia displays, while the bloody procedure was going on.

In relation to the key aims, concerns and motivations that propelled her for embarking on such a project, Orlan frequently states that she is not against cosmetic surgery but opposed to the 'standard criteria of beauty that cosmetic surgery imposes on female and male bodies'. ${ }^{6}$ She speaks in detail about her intended rejection of the normative morphologies reproduced by conventional uses of cosmetic surgery. Hence, her performative-surgical project emerges as a critique of the Western beauty standards imposed particularly on women, by means of employing the medium of cosmetic surgery for the first time against its intended purposes - as a means of transformation of oneself. ${ }^{7}$ Orlan, in that sense, joins the previous chapter's objects of focus - Helen Garner's and Luke Davies' novels - in her corporeal investigation, insofar as she throws a serious challenge towards the notion of body coded by cultural, in particular, patriarchal discourses. As such, Prowse's argument that the reconceptualisation taking place in both novels might destabilise 'the constraints of spatiotemporal constructs upon the (female) subject', ${ }^{8}$ seems to be in line with the way Orlan works to disrupt the culturally accepted standards and expectations of beauty that are perpetuated by patriarchy. Yet, even though the critique of the essentialised notions of beauty in contemporary Western society is one of the most obvious tasks of Orlan's project, her motivations for undertaking these surgeries are much more profound than that. As such, the artist refuses to limit her investigation to purely these paradigms and considers the feminist aspect as 'just a fraction of her work', ${ }^{9}$ which in fact, explores more complex issues regarding the human body and identity. Defining her performance surgeries as 'Carnal Art', Orlan says her 'work and its ideas incarnated in flesh questions about the status of the body in our society and its evolution in future generations via new technologies and upcoming genetic manipulations.' ${ }^{10}$

6 Orlan, 'Interview,' The South Bank Show. dir. David Wiles. ed. and pres. Melvyn Bragg. London Weekend Television, 1997.

7 In relation to this, Orlan states: 'I am the first artist to use surgery as a medium and to alter the purpose of cosmetic surgery.' Orlan, 'Intervention,' 324.

8 Nycole Prowse, 'Possibilities from the Peripheries: Time, Space and the Body in the Australian Drug Writing of Helen Garner and Luke Davies', in this volume. Modification, ed. Mike Featherstone (London: Sage, 2000), 180. 
She defines another aim of hers as questioning the taboos pertaining to the violation of the bodily integrity in Western culture, by not feeling 'threatened by this collective, ancestral fear of interfering with the integrity of the body ... that the body, formerly viewed as God's masterpiece, is sacred and untouchable, not to be transformed.'11 In addition to Orlan, writer Jane Goodall neatly expresses the motivation behind her surgical piece: 'Orlan's determination to interfere with her given identity provides the sustaining motivation for her whole oeuvre.'12 In a similar examination, critic August Ruhs characterises her project as follows: 'Orlan irreversibly alters her physical and social identity she literally sacrifices it to art through plastic surgery, so that she transcends the limits of traditional body art in an unprecedented way - hardly any other artist achieves this aim as radically as she does.' ${ }^{13}$ Hence, it follows from all of the above that, at the heart of Orlan's performative Carnal Art project is her investigation of the capacities, limits and mutability of the body and identity through the advances in biomedical sciences and various forms of contemporary technology. ${ }^{14}$

The entire project of The Reincarnation of St. Orlan, which investigated such possibilities of bodily manipulation and mutation through new technologies and medical interventions, took place over an extended period of time, spanning from 1990 to 1993. Each of Orlan's operations was designed to alter a specific feature and had a theme, including: Carnal Art, This is My Body-This is My Software, I Have Given My Body to Art and Identity Alterity. ${ }^{15}$ Based on the removal (incision, cutting, extracting and reduction) and addition (implanting, injection, suture), these series of transformations included facial modification, insertion of prosthetic and silicone implants, liposuction from her thighs and reshaping of her ankles, knees, hips, waist and neck. ${ }^{16}$ These radically

11 'Harlequin Coat,' Sk-Interfaces: Exploding Borders - Creating Membranes in Art, Technology and Society, ed. Jens Hauser (Liverpool: FACT and Liverpool University Press, 2008), 83 .

Jane Goodall, 'An Order of Pure Decision: Un-Natural Selection in the Work of Stelarc and Orlan,' Body Modification, ed. Mike Featherstone (London: Sage, 2000), 155.

13 August Ruhs, 'Orlan Metamorphoser,' Body as Membrane nv (1996): 46.

14 The images of Orlan's performance-surgery series might be seen on the artist's official website. Viewed on 5 August 2015, http://www.orlan.eu/works/performance-2/; and http://www.orlan.eu/works/photo-2/nggallery/page/2.

15 Kathy Davis, 'My Body is My Art': Cosmetic Surgery as Feminist Utopia?' The European Journal of Women's Studies 4.1 (1997): 26.

16 C. Jill O'Bryan, Carnal Art: Orlan's Refacing (Minneapolis: University of Minnesota Press, 2005), 15 . 
disfiguring and refiguring processes, however, neither ended in an integrated whole or a unified beauty, nor were intended to create such a result. Rather, Orlan acquired some discordant new features, a type of fragmented, uncertain and ambiguous appearance that resists any fixed definition or coherent meaning. Arguing that the artist looks 'distinctly unnatural in appearance,' performance studies scholar Philip Auslander states that 'the work's critical edge derives from the failure of the subject to become the desired image. ${ }^{17}$ With her facial disfigurement and 'failure ... to become the desired image,' particularly with the forehead implants she had on her temples to create two horn-like bumps, Orlan deviated from the human body's normative morphology and socio-cultural norms of ideal self. Therefore, the artist became the direct result of her performances; she converted her corporeal space literally into a malleable artwork, into a 'site of public debate' by continuously refashioning her actual physicality. ${ }^{18}$ Accordingly, the artist's experimental attitude towards the body, by treating it as mutable material that could be modelled and remodelled infinitely, visualised her embodied space in a constant process of transformation and change throughout the duration of the surgical performances. In that sense, the corporeal respatialisation at stake here has strong resonances with Garner's reconceptualisation of the drugged space in her novel, as examined by Prowse in the preceding chapter. While presenting a different slant on the theme of respatialisation, the spatio-corporeal fluidity and permeability of the female subject-body engendered by the use of drug trope in Garner's Monkey Grip, nevertheless, are equally at play in The Reincarnation of Saint Orlan. Beyond these physical alterations Orlan experienced in the spatio-temporal coordinates of her body, the images of her mutating flesh were further translated into digital representations and disseminated across the electronic space during the surgeries by means of digital networks of satellite and real time transmission. This, arguably, enabled her body to experience further spatial changes and become even more exteriorised. In that respect, the prominent body art scholar Amelia Jones rightfully observes that the artist is 'enacting herself (and literally rearranging her body/self) through technologies of representation as well as medical technology, her body/self is experienced (both by herself and by her audience) in and through technology'19

17 Philip Auslander, From Acting to Performance: Essays in Modernism and Postmodernism (London: Routledge, 1997), 131.

18 Orlan, 'Carnal Art Manifesto,' viewed 20 February 2010, http://orlan.net.

19 Amelia Jones, Body Art/Performing the Subject (Minneapolis: University of Minnesota Press, 1998), 227; Orlan's official portrait can be seen in the following link: https:// sumnonrabidus.files.wordpress.com/2011/02/orlanı.jpg. 
In her subsequent series of self-portraits entitled Self-Hybridizations, Orlan continued to deal with the body and its experimental modifications and mutations, this time using digital technology instead of the scalpel to transform the body. Hence, in this section, I further my discussion on Self-Hybridizations series, a complementary body of work to Orlan's surgery-performances. Exploring similar themes such as beauty and identity, this series of computer-generated self-portraits were created by digitally combining the photographs of her surgically altered face with the signifiers of beauty of non-Western cultures: images collected from various pre-Columbian, American-Indian and African sculptures and masks. For Self-Hybridizations, the artist worked with a digital imaging specialist and utilised 3-D modelling techniques to produce digital photographic portraits in which her modified facial features were further amalgamated with the stylisations, ritualistic deformations and scarifications of these civilizations. ${ }^{20}$ The resulting images reveal the multiplying potential of transformation made possible by new technologies in the digital realm. They offer many variations; Orlan is digitally morphed into what appears to be female figures with bizarre protuberances, enlarged noses, deformed skulls and tattoos. ${ }^{21}$ In relation to these photographic pieces, which blend her existing facial coordinates with the primitive disfigurements associated with past tribes, Orlan asserts that they are the 'images of mutant beings whose presence is thinkable in a future civilisation that would not put the same pressures on bodies as we do today'. ${ }^{22}$ Indeed, most of the images in the series confound the viewers' expectations of the human corporeality, with their obscured forms such as swollen foreheads, elongated necks, extremely distorted noses and inscribed skin. Combined with Orlan's own modification - the bumps on her forehead - their type is difficult to distinguish. ${ }^{23}$

$20 \quad$ Christine Schultz-Touge, Orlan: Carnal Art (Paris: Flammarion, 2004), 166.

21 So far three series have been realised, as Eugenio Viola discusses in detail: 'In Self-hybridations précolombiennes (1998-2000), the artist used morphing software to hybridize her new face with masks and votive statuettes of the Olmecs, Mayas, Incas, and Aztecs. The Self-hybridations africaines (2000-2003) were obtained by mixing a portrait of the artist with ethnographic photographs of African tribes...In the Selfhybridations amérindiennes (2005-2007), Orlan hybridized her own image with portraits belonging to various American tribes.' Orlan, 'The Narrative,' Orlan: The Narrative, ed. Lorand Hegyi, Joerg Bader, Eugenio Viola, Marcela Iacub, Donald Kuspit, Peggy Phelan and Orlan (Milano: Edizioni Charta, 2007), 45-47.

22 Orlan qtd. in O'Bryan, Carnal Art, 134.

23 The images of Orlan's Self-Hybridizations series are available on the artist's official website. Viewed on 5 August 2015. http://www.orlan.eu/works/photo-2/nggallery/page/2. 
Since the possibilities of self-transformation are explored through digital manipulation techniques and computer morphing technology, with this particular project, Orlan was able to eliminate the high risks or threats involved in experimenting with the real body tissue. Yet, due to the very same reason, it could also be argued that the pieces that comprise Self-Hybridizations series might, in fact, be lacking the depth of her surgical alterations in her Reincarnation project, insofar as these works are not based on the transformation of the material flesh, as explained by the artist herself: 'Contrary to what I did with surgical operations, the self-hybridisation series do not inscribe the transformations in my body (my phenomenical body) but in the pixels of my virtual body, mixed with non-organical matter and my own representation, itself reworked by surgery'. ${ }^{24}$ Nevertheless, the malleability and permeability of the body achieved throughout this project, are sufficient to create a serious interrogation of human subjectivity, by highlighting, as Orlan says, 'multiple, evolving, mutating identities. ${ }^{25}$

As this discussion has indicated, the radical disfigurings and refigurings of Orlan's embodiment brought about by cosmetic surgery and more recently by digital morphing technology are unique works of metamorphosis, which seriously complicate the understanding of body's relation to space. Lying on the operating table with her flesh cut open, Orlan makes her body entirely mutable and prompts a radical rethinking of the basic assumptions about the stability and the unity of the corporeal self. In a similar manner, her digital self-portrait series significantly questions the fixed and the static codes that structure the body in conventional humanist configurations. Her Carnal Art projects, therefore - whether digital or material - present a consistent preoccupation with the theme of bodily transformation that evokes an understanding of corporeal respatialisation. As these projects move towards complex spaces where the human body is depicted as a melding of biology and technology, the clear distinctions between the spaces that belong to self and other, human and non-human, cease to exist. Dominant identity categories are disrupted and fixed, organic bodily boundaries are contested. Amidst such boundary-breaking encounters, Orlan's work points out to a need to rearticulate the changing perceptual limits of the bodily space. In confronting these amalgamations of organic human flesh and inorganic prostheses during the performative-surgeries, how is one to articulate the human self? What is it that emerges within the complex interchanges between various human and non-human parts, the flayed flesh

\footnotetext{
24 Ibid., 134.

25 Orlan, qtd in Peg Zeglin Brand, 'Bound to Beauty: An Interview with Orlan,' Beauty Matters, ed. Peg Zeglin Brand (Bloomington: Indiana University Press, 2000), 305.
} 
and technological apparatus? How does this digital blending of various human identities that belong to different civilisations of different times reflect back on the body, on the creation of the individual? Having constructed a detailed analysis of Orlan's complex body projects, the following section critically examines Deleuze and Guattari's formulation of the body through their theory of becoming-other and its attendant vocabularies as constituting the underpinning framework for addressing these various questions that accompany the artist's works.

\section{4}

\section{A Deleuze-Guattarian Perspective towards the Body: Subject as Becoming-other}

In terms of identity, Deleuze's philosophy can be seen as a critical attempt to leave behind the traditional notion of the subject with any fixed essentiality. In his single authored works, as well as his collaborations with Guattari in their two central texts, Anti-Oedipus and A Thousand Plateaus; Capitalism and Schizophrenia, he rigorously criticises all self-bounded, autonomous and static forms of being that have no connections to their outside. His philosophy is, rather, grounded on a more open-ended, processual and relational ontology at the base of which are the dynamic processes of becoming. Accordingly, for Deleuze, 'the struggle for [modern] subjectivity presents itself, therefore, as the right to difference, variation and metamorphosis. ${ }^{26}$ Becomings, in this sense, are processes instigating the transformation of self - not transformation from one static state of being to another - rather they imply a processual metamorphosis, perpetual transition or a constant differentiation that destabilises the fixed, static and unitary understandings of identity. In short, the notion denotes the very dynamic of change, as Deleuze and Guattari write: 'Becoming produces nothing other than itself ... What is real is the becoming itself, the block of becoming, not the supposedly fixed terms through which that which becomes passes.'. ${ }^{27}$ As thinking oriented towards continual movement and ongoing process, then, the logic of becoming tends towards no spatial end result or a finalised, resettled identity.

Such a process, however, does not materialise all by itself: becomings take place through heterogeneous encounters and multiple connections between different forms and force fields. Rosi Braidotti's work, in dialogue with Deleuze

26 Gilles Deleuze, Foucault, trans. Sean Hand (Minneapolis: University of Minnesota Press, 1988), 106.

27 Deleuze and Guittari, $A$ Thousand Plateaus, 238. 
and Guattari's writings, also draws attention to the relational aspect of becoming which is 'about affinities and the capacity both to sustain and generate inter-connectedness', ${ }^{28}$ thus, she adds, it is 'external and interrelational. ${ }^{29}$ As a radical form of interconnectivity, it is also crucial to highlight that the theory of becoming involves not only human but also non-human modes of life and their complex interrelationships. It emphasises the shifting and passing interactions between multiple and divergent things, such as human and machine, human and animal, organic and inorganic, and their respective territories. For Elizabeth Grosz, following the work of Deleuze and Guattari, this account cultivates the interconnections between entities 'both human and nonhuman, animate and inanimate, linking organs and biological processes to material objects and social practices, ${ }^{30}$ while for Braidotti, it highlights the multiple relational bonds with a variety of 'external forces, of the non-human, inorganic or technological kind'. ${ }^{31}$

Because such a perspective shifts the focus on relationality and connectedness, subjects can no longer be confined to neatly defined ontological systems or individuated beings with any fixed spatiality. Instead, they can only be grasped as transitory and connected modes of existence, always becoming more and other than themselves through their convergences and alliances with other bodies and external milieus. This is to say that subjectivity 'necessarily changes in nature as it expands its connections. ${ }^{32}$ If subjects can pass and slide into each other, interpenetrate with other bodies, then, the strictly polarised, discrete and self-sustaining subject cannot be upheld. This kind of interconnected and interdependent understanding of ontology proves to be central to Deleuze and Guattari's philosophy and is constitutive of their subject, which is in a constant exchange with a series of other biological, social and technical modes of life:

There is no such thing as either man or nature now, only a process that produces the one within the other and couples the machines together ...

28 Rosi Braidotti, Metamorphoses: Towards a Materialist Theory of Becoming (Cambridge: Polity Press, 2002), 8.

29 Ibid., 83.

30 Elizabeth Grosz, Volatile Bodies: Toward a Corporeal Feminism (Bloomington: Indiana University Press, 1994), 165 .

31 Rosi Bradiotti, 'Affirming The Affirmative: On Nomadic Affectivity,' Rhizomes 11/12 (2005/2006): np, viewed on 15 January 2016, http://www.rhizomes.net/issue11/braidotti .html. 
the self and the non-self, outside and inside, no longer have any meaning whatsoever. ${ }^{33}$

From this perspective, bodies and selves are always implicated in their exteriority; through heterogeneous connections and alliances they ceaselessly form with their surrounding terrains. What Deleuze proposes then, in his collaborations with Guattari, is an actively relational, dynamic, shifting and open-ended subject in-process that is 'on the periphery, with no fixed identity, forever decentered, defined by the states through which it passes. ${ }^{34}$ Considering this continual involvement with the external environments, the body as an organically determined, exclusive unity or an ordered, unified whole becomes inoperable in this context. Accordingly, Grosz aptly defines how this account refuses 'to subordinate the body to a unity or a homogeneity of the kind provided by the body's subordination to consciousness or biological organization.'35 In her discussion of Deleuze and Guattari's notion of becoming, she further remarks that the body is radically reconfigured:

in terms of what it can do, the things it can perform, the linkages it establishes, the transformations and becomings it undergoes, and the machinic connections it forms with other bodies, what it can link with, how it can proliferate its capacities - a rare, affirmative understanding of the body. ${ }^{36}$

Here, Grosz points to the corporeal model that brings about a dismissal of unifying, homogeneous ground and a focus on the body's capacity to be open to the possibilities of change through multiple linkages and associations.

Finally, this kind of theorisation necessarily entails a certain move away from the binary logics associated with traditional Western thinking, since the body is not defined in its ontological interiority, but rather in its interactions and intertwinements with other bodies and entities. As such, a systematic concern apparent in Deleuze and Guattari's texts is an attempt to undo a series of dualistic structures and categorical orders such as inside/outside, human/ machine, human/animal, organic/inorganic and biology/culture among other binary pairs. This results in an expanded sense of ontology, in which all entities

33 Deleuze and Guattari, Anti-Oedipus: Capitalism and Schizophrenia, trans. R. Hurley, M. Seem and H.R. Lane (Minneapolis: University of Minnesota Press, 1983), 2.

34 Ibid., 20.

35 Grosz, Volatile Bodies, 164-165.

36 Ibid., 165 . 
and things are situated on same field 'which applies equally', Deleuze and Guattari write, 'to the inanimate and the animate, the artificial and the natural., ${ }^{37}$ This boundary-crossing dimension of the theory of becoming has also been astutely observed by Braidotti, who states that the lines of becoming favour "the overcoming of the dualism Self/Other" and they 'inevitably and necessarily move into the direction of the "others" of classical dualism. ${ }^{38}$ Having provided the philosophical backdrop of this chapter, the task of the following section is to interweave the theory of becoming outlined here with the practice of Orlan, which demonstrates a strong preoccupation with the production of external relations and connectivities, implying a strong sense of corporeal respatialisation.

Theory of Becoming and Orlan's Corporeal Metamorphosis

As a theory that foregrounds the ongoing production of relational encounters between heterogeneous domains or fields, Deleuze and Guattari's becomingother proves useful for elucidating the complex entanglements of varied human and non-human elements in Orlan's body-based practice, and for drawing out the various degrees of metamorphosis her body undergoes in her Carnal Art projects. In relation to these continual corporeal alterations and the accompanying disruption of the fixed categories of identity in her surgical project, performance scholar Jill O'Bryan argues that the artist's body 'always appears to be in the process of forming' and her identity is 'of one who has exacerbated a state of flux (with surgery) in a live (and therefore already continually changing) human body' ${ }^{39}$ In a similar analysis to O'Bryan, Auslander argues that Orlan's work portrays 'a self for which identity is mutable, suspended, forever in process.' ${ }^{40}$ Indeed, the constant disfigurings and refigurings of the artist's body through a series of nine extensive cosmetic surgeries perform the mutability and instability of her bodily identity by marking her transition from a static and fixed state of being to a self-generating and processual one. According to O'Bryan, moreover, they do so 'by reopening the body-boundary which must remain closed in order to guarantee the level of repression necessary for the maintenance of organized subjectivity' ${ }^{\prime 1}$ Indeed, Orlan's intimate exploration of her own flesh seriously disrupts the notion of an exclusive, unified human

Deleuze and Guittari, A Thousand Plateaus, 254.

38 Bradiotti, Metamorphoses, 119.

39 O'Bryan, Carnal Art, 54.

40 Qtd in O'Bryan, Carnal Art, 31.

41 Ibid., 131. 
self with any inert nature or stable form of organisation. It discloses the body not as a self-contained, bounded entity with clear delineations between inside and outside, rather as a permeable, transitory and shifting terrain in the public arena.

Accordingly, Orlan's fleeting states of being, which move from one ontological configuration to the next, and her body that always remains in the process of transition throughout the series of surgery-performances become the visual manifestation not of a being, but of a becoming. As a matter of fact, since the artwork taking place is the very making of Orlan, the artist performs her own becoming - becoming-other than what she is - both in an ontological and artistic sense. To begin this analysis, Deleuze and Guattari's emphasis on becoming as a movement that strives towards no particular end-state or as a pure process that 'produces nothing other than itself'42 has specific relevance to Orlan's series of surgery-performances that likewise, value process over result. In her statement where she defines her performative surgeries as Carnal Art, Orlan emphasises that:

the plastic result was not the objective - any result would have served my purpose ... What really matters is the process, what happens in the operating theatre, and the fact that my body has become an area for public debate. ${ }^{43}$

This focus on process and what happens in between - away from a finished and spatialised end product - suggests that Orlan does not aim to achieve or adhere to a reconfigured or finalised form of identity: an effort that would fall back onto a static definition and sedentary being. According to Orlan's own account, her surgical project as well as her digital self-portraits does not imply a reaffirmation of the subject; instead of representing a mere 'constructed re-personalization,' they foreground 'a destabilization of the subject.44 Subsequently, this concern with the body as a temporal process as opposed to the body as a spatial outcome place both of her projects in strong resonance with the notion of becoming that conceives and expresses change in itself.

Deleuze and Guattari's emphasis on the relational aspects of becoming via an open-ended involvement with the outside, and their radical reconfiguration

\footnotetext{
42 Deleuze and Guittari, $A$ Thousand Plateaus, 238.

43 Orlan, 'Carnal Art Manifesto.'

44 Qtd in Rocio De la Villa, 'Orlan's Wardrobe', Orlan + Davidelfin: Suture, Hybridisation, Recycling, ed. Rocio De la Villa and Pedro Alberto Cruz Sanchez (NC: Murcia Cultural, 2009), $3^{2-35}$.
} 
of the body in terms of contingent connections with various life processes both human and non-human - provides a powerful means to unpack the complexity of encounters taking place during Orlan's surgical operations. As such, the relational ontology of becoming that Deleuze and Guattari develop, articulates some of the same kind of connections and interactions in which Orlan is interested: interactions that occur between heterogeneous realms - biological and artificial, organic and inorganic, figuration and disfiguration etc. During the surgery-performances, Orlan's skin is literally peeled away from her body and according to the cultural theorist Parveen Adams, in viewing it, we 'find ourselves unhinged in a space that refuses to organize an inside and outside.,45 The audiences watching the event in the galleries witness the bloody disorganisation and the carnal quality of the flesh, according to Ince, by gaining visual access into the 'fragmented body composed of mass of internal organs, fluids, tissue and muscle' through the incisions and open wounds in Orlan's body ${ }^{46}$ Given this context, Orlan's project fundamentally reverses the relationship of the interior to the exterior by turning the body inside out and, therefore, fractures the spectators' understandings of the body's spatial boundaries. The way Orlan describes her Carnal Art, as 'a way of refiguring yourself, of vacillating between disfiguring and refiguring' ${ }^{\prime 47}$ further intensifies the destabilisation of neatly organised and strictly bounded corporeal space.

The surgical opening of the artist's body during the performances, moreover, brings her into continuity with other bodies by becoming increasingly permeable to the outside. During the processes of cutting, opening and suturing of her skin, technological parts as various inorganic implants and biomechanical prostheses are inserted and implanted into Orlan's organic flesh, into her bones. Hence, the surfaces of self and other, biological and technological fuse and fold into one another, collapsing the corporeal borderlines. Said another way, as the surgeon's scalpel cuts through the skin, her body is penetrated by other elements, it incorporates them into itself and blends with external parts, provoking an exploration of unfixed corporeal coordinates. Performance scholar Michelle Hirschhorn reflects on the unsettling experience of witnessing these bloody procedures by expressing that there is 'something profoundly destabilizing about watching a woman's face being sliced open, seeing her bleed, seeing medical instruments moving indiscriminately under her skin,

45 Parveen Adams, 'Operation Orlan,' The Emptiness of the Image: Psychoanalysis and Sexual Differences (New York: Routledge, 1995), 156.

46 Kate Ince, Orlan (Oxford and New York: Berg Publishers, 200o), 52.

47 'Orlan Interviewed' by Hans Ulrich Obrist, in Orlan: Carnal Art, ed. Christine SchultzTouge (Paris: Flammarion, 2004), 199. 
that words alone would simply not convey.'48 Indeed, this is a body with extremely permeable boundaries, a body, according to Grosz, which exceeds its biological designation, 'to open itself up to prosthetic synthesis, to transform or rewrite its environment, to continually augment its power and capacities through the incorporation and into the body's own spaces and modalities.'49 Accordingly, by subjecting her body to medical technologies, Orlan investigates the possibilities associated with the breakdown of the barriers between internal and external, natural and artificial, human and non-human spaces, as well as their potential couplings. It is in this respect that, my reading of Orlan's live performance comes close to Prowse's reading of the dissolution of spatial boundaries as it is depicted in Garner's Monkey Grip in Chapter 1. Common to both pieces, is the creation of spatial connections, interconnections of the self with its various environments, which, in turn, act as a catalyst for the corporeal respatialisations that go beyond binary constructs. While such spatial connections are established through the narcoticising of the urban and the rural, the self and the environment in Prowse's examination, it takes the form of entanglements of the organic human flesh and artificial technological constructs in Orlan's art practice.

To return to the main point of the current argument, within Deleuzian conceptualisation, then, the body becomes an assembled, multiple, dynamic and shifting site of human-machinic interaction. These boundary-crossings and reciprocal exchanges between synthetic and organic elements that open the static homogeneity of Orlan's body to continuous variation, as well as its medical disassembly and reassembly by prostheses, silicone and sutures foreground the body's various technological becomings. The effects of these modifications are in the form of lack, enhancement, displacement or extension, or the assembly of unrelated body parts. These modifications of the body's fleshy territory, in turn, dramatically dislocate Orlan's embodied self from its fixed spatial organisation. On this account, her surgical experiments lead to a radical reconfiguration of her flesh as a heterogeneous site that disturbs traditional spatial boundaries of where the human being ends and the world outside begins. One might say that, searching for an alternative to the view that regards the embodiment as a sealed entity, in Grosz's words, as a 'singular, organised, self-contained, organic body ${ }^{\prime 50}$ with clear-cut separations between inside and

48 Michelle Hirschhorn, 'Orlan: Artist in the Post-Human Age of Mechanical Reincarnation: Body as Ready (to be re-) Made,' Generations \& Geographies in the Visual Arts: Feminist Readings, ed. Griselda Pollock (London: Routledge, 1996), 112.

49 Grosz, Volatile Bodies, 187-188.

5o Ibid, 172 . 
outside, biology and technology, Orlan performs a highly metamorphic self that ongoingly changes by spreading, shifting and overstepping onto other territories, linking to other domains, technologies, spaces in a multiplicity of connections. Amidst such dynamic and complex connectivities, the audiences watching the bloody transfiguration of her flesh in the galleries, simultaneously witnesses the production of an indeterminate, inexact and uncertain corporeal ground. As a body that effectuates its own metamorphosis through the external relations it forms with its various others, Orlan's corporeal self, in turn, is closely aligned with Deleuzian paradigm of the body in its significant move away from a static, unified, self-enclosed space towards a collective site of ongoing interactions. As such, within his formulation, it becomes 'the product of an assemblage - which is always collective, which brings into play within us and outside us populations, multiplicities, territories, becomings, affects, events.' ${ }^{51}$

Making new connections and forging alliances between different fields also appear as the core element of Orlan's self-portrait series Self-Hybridizations not on a material but a digital level. Employing computerised transformation, Orlan, once again, becomes the embodiment of multiple connections between the aesthetics of different spaces and times; intertwinement of ancient and contemporary, visceral and virtual, civilised and primitive, human and nonhuman dimensions in one physical unit. More precisely, the facial associations she configures between her own surgically altered face and the facial masks of different races and cultures destabilise the separation of individuals into distinct categories, and present their potential fusions that can endlessly be modulated. The convergences and intersections of these different realms of experience, in turn, recreate the body as a complex site of relationality, while opening its personal, homogeneous unity to the possibilities for becomingother-than oneself. According to Orlan, the images that constitute this project 'have a relationship with the body which is particularly disturbing for us, which completely challenges us and which is very intense... This is the idea of entering into the skin of the other.'52 By 'entering into the skin of the other', Orlan brings an important dimension into the picture, namely the possibilities of a transitory and interconnected form of existence, the active process of passing and mutating into other identities. In that respect, by means of endless alteration and amalgamation the digital realm offers, Orlan's self, once again, becomes evocative of an uncontained corporeal space that extends

$5^{1} \quad$ Gilles Deleuze and Claire Parnet, Dialogues, trans. H. Tomlinson and B. Habberjam (London: The Athlone Press, 1987), 51.

52 Qtd in Ayers, 'Serene and Happy and Distant: An Interview with Orlan,' 177. 
towards the territories of other bodies, this time the bodies of other cultures and other time periods. The 'immediate relation with the outside' that Deleuze and Guattari mention as constitutive of ontology, ${ }^{53}$ in that sense, seems to find an aesthetic parallel in the artist's digital self-creation. Subsequently, the multiplicity of bodily differences and irregularities at play within these composite images - protruding eyes, skin lesions, enlarged noses and deformed skulls - propels Orlan's embodiment from being mere human to something else, to an open field of becomings that make manifest 'an inhumanity immediately experienced in the body as such,.$^{54}$ In the process, like her previous bloody procedures, and the drug trope in Prowse's ${ }^{55}$ analysis, these differences steer her bodily image towards an ambiguous, heterogeneous and imprecise state that defies categorical distinctions and ontological assumptions. In order to better address this metamorphic, heterogeneous and indeterminate dimension of corporeality opened up both in The Reincarnation of St. Orlan and Self-Hybridizations, it is also necessary to invest in the vocabularies of betweenness and intermezzo that the theory of becoming brings about, notions which are discussed in more detail in the next section.

\section{6}

\section{Being In-between, Becoming Intermezzo}

As a model of radical relationality and connectedness, as argued earlier, the theory of becoming also necessitates a certain overcoming of dualistic structures and binary oppositions that have long dominated Western philosophical thought. This emphasis on the non-dualistic continuity between disparate fields and forms introduces a particular aspect of becoming: the strategy of being in-between. Deleuze and Guattari's conception of becoming, as a movement that connects and passes between binary terms, 'frees itself from the point, and renders points indiscernible'. ${ }^{56}$ The attention, thus, is shifted from the fixed points or states to the movement itself, to the relational passage and transitional states between those terms. Becoming, sweeping away fixed identities, therefore, emerges in a relational middle:

Between things does not designate a localizable relation going from one thing to the other and back again, but a perpendicular direction,

\footnotetext{
53 Deleuze and Guittari, $A$ Thousand Plateaus, 377.

54 Ibid., 273 .

55 Prowse, in this volume.

56 Ibid., 294.
} 
a transversal movement that sweeps one and the other away, a stream without beginning or end that undermines its banks and picks up speed in the middle. ${ }^{57}$

As a logical outcome of these middle spaces, Deleuze and Guattari proceed with their analysis by discussing how becomings take place in-between entities or subjects: 'A becoming is neither one nor two, nor the relation of the two; it is the in-between'. ${ }^{58}$ Grosz also explains the characteristics of these in-between areas as such: 'the position of the in-between lacks a fundamental identity, lacks a form, a givenness, a nature. Yet it is that which facilitates, allows into being, all identities, all matter, all substance. It is itself a strange becoming' ${ }^{59}$ In sum, as a metamorphic movement between the terms it connects, the space of becoming is 'always in the middle, between things, interbeing, intermezzo' ${ }^{60}$

Because becoming operates in the passing intervals or shifting interstices of ontological orders and categorical distinctions, it provides a way to compose a self that does not differentiate between human and non-human, or biology and technology. That is to say, becomings, which offer ways of inhabiting all sorts of betweens, positions existence in the middle - in the middle of nature/ artifice, human/animal, organic/inorganic and so on. This mode of existence in the intermediary spaces, in turn, allows a vision in which 'a dualism or dichotomy can never be assumed'.61 It, therefore, binds even the most discrete forms, milieus and bodies into a dialogue with each other; hence it enables the construction of mobile, non-binary, heterogeneous, blurred arrangements among seemingly divergent elements and distinct forms of life. Within such a context, according to Deleuze and Guattari, the self becomes 'only a threshold, a door, a becoming between two multiplicities'. ${ }^{62}$ Accordingly, the following section continues to deploy the theory of becoming as an elucidating strategy to tease out the various transitional, uncertain, in-between corporeal spaces opened up in Orlan's practice - the spaces defined in contradiction to a discretely organised, self-enclosed, organic body.

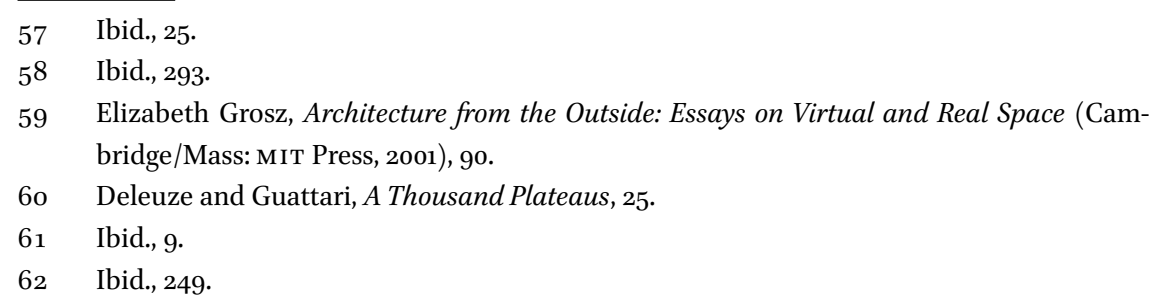



Subject

Deleuze and Guattari's formulation of the notion of becoming that proceeds via in-betweens or intermezzos - relational, open-ended and mutating spaces that connect multiple and divergent forms - provides a powerful theorisation to articulate Orlan's body of work, which is capable of forming collective spatial arrangements of interpenetrating elements without yielding to a unified, stable centre. While Orlan's multifaceted performance series visualises a radical approach of art, science, medicine entanglement that collapses their disciplinary borderlines, it is also a drastic alteration of the bodily space, which explores the intertwinement of corporeal human and non-human technology. As a matter of fact, by opening her body to the intrusion of a varied range of inorganic implants and prostheses that meld with her natural, corporeal properties, Orlan becomes a figure of interrelationality in one embodiment. The dissolution of the categories separating the organic flesh from the technological apparatus, the human from the non-human into an extended space of linkages and alliances yields to a corporeal ambiguity, diversity and indeterminacy that are disturbingly in-between. Similarly, Orlan's experimentation with primitive disfigurements, past tribal and ritual deformations in Self-Hybridizations series radically disrupts the recognisable human forms and dramatises the intertwining of self and other. With their perplexing forms, these images are appealing but uncertain in appearance. Seen in these terms, Self-Hybridizations contributes to the bodily ambiguity played out during the artist's preceding performative-surgery series and highlights a plural aesthetics that operate in-betweens of various bodies of different morphological, sociological and spatio-temporal origins.

As a logical outcome of these complex convergences between divergent forms and phenomena in Orlan's work, disrupting dualisms becomes a central aspect that makes up The in Reincarnation of Saint Orlan and Self-Hybridizations. Indeed, these projects present a radical attempt to challenge the binary distinctions and hierarchical categorisations between the spaces that belong to corporeality/ technology, natural/artificial, self/other, human/non-human, interior/exterior, visceral/ virtual, ancient/contemporary. While several scholars have already noted the binary-crossing nature of Orlan's body of work, I assert that her multi-media surgical project, along with her more recent digital self-portraits - which situate themselves outside the dualistic structures surrounding nature, artifice, human and non-human - in fact operate within the intermediary spaces or interstitial passages of Deleuze-Guattarian becomings. O'Bryan, for example, notes that, 'binaries that become unleashed from Orlan's 
work are subject/object, male/female, self/other, natural/unnatural, interior/ exterior, beauty/the monstrous, art/medicine and so on.'63 Indeed, Orlan's entire work conveys an understanding that challenges the hierarchical bodily structures in terms of dualities that separate man from woman, beautiful from grotesque, human from non-human, real from virtual, natural from artificial, instead it consists of radical forms of bodily exchanges and relational linkages between apparently contradictory terms. The way she makes use of diverse forms of technology to compose her art signals towards boundary-crossing couplings between the real and the synthetic, as well as a profound connectivity with otherness. It, thus, turns her corporeal subjectivity into a heterogeneous and collective site constituted by diverse spatial arrangements between organic, inorganic, technical, natural, artificial components that continuously resonate with one another. It is my key assumption that this strategy of opening up her corporeal space to exteriority, to multiple elements in a dynamic interaction posits Orlan's artistic act in-between milieu of pure metamorphoses, in the non-binary space when different realms of experience intermingle, (human/ non-human/ machinic/ organic/ inorganic/ real/ digital/ figuration/ disfiguration), which characterises the intermezzos of becomings. The work of Orlan, therefore, reveals further resonances with Prowse's analysis of the female drug literature, particularly with Garner's Monkey Grip, in that they are both providing potent instances of in-between spaces that have the potential to go beyond the dichotomised structures and fixed spatio-corporeal boundaries. While their mediums, approaches and issues of concern vary diversely, the drug trope in Monkey Grip that dramatises the temporal and spatial interstices between the dreamed drug spaces of the psyche and the "real" fragments of urban space'64 as well as the blended in-between realms of nature/subject, urban/rural display striking parallels with Orlan's work, which equally generates a complex, relational and collective space.

This collectivity of connections, in turn, renders Orlan's art as unnatural, uncertain, ambiguous, transitory but ultimately transformative. These selftransformative processes occur through the expansive capabilities of these ambiguous, inexact spaces that express an openness to other bodies, technologies, objects and spaces. This kind of strategy: 'to be-between, to pass between, the intermezzo' Deleuze suggests together with Guattari, is the only way to bypass the oppositional discourse and get outside the dualistic logic. ${ }^{65}$ One has to accentuate this perspective, as it might provide possibilities of a less enclosed

\footnotetext{
63 O'Bryan, Carnal Art, 116.

64 Prowse, in this volume.

65 Deleuze and Guittari, $A$ Thousand Plateaus, 227.
} 
and more connected existence, capable of engaging the in-between realms of becoming that are characterised by movement and processual change. As a matter of fact, Orlan's bodily space is always situated in between; in between figuration and disfiguration, in between real and virtual, in between natural and artificial, in between surgeries, in between processes of recovery, in between civilised and primitive, in between states of self and other. This would be a precarious body that emphasises its imprecise, transitional, indeterminate constitution by occupying a middle ground; an existence continually becoming-other-than-itself.

\section{Conclusion}

This chapter was an exploration into the dynamics of Orlan's art practice within a Deleuze-Guattarian framework. By taking the authors' conceptual tools into other fields - the milieus of the artist's complex body project - it attempted to produce lines of connections between their projects. It is the notion of becoming that seems to capture most fully the continual change the artist experiences, her body's dynamic, experimental, transitional states of being. Orlan, then, might be said to embody a being 'but only the being of becoming', as Deleuze would understand. ${ }^{66}$ Elsewhere in this chapter, I have pointed to the ways in which the artist goes beyond traditional assumptions in which bodies are formulated as closed, integral and static unities according to preconceived schemes and spatial organisations, by approaching embodiment as a never-ending temporal process of becoming. In so doing, Orlan brings a range of alternative and unthought of corporeal possibilities into existence, she induces bodily ambiguities, uncertainties and differences that throw a potential challenge to the fixity of identity, in keeping with Deleuze and Guattari's articulation of difference over sameness.

In sum, I see Orlan's complex body project as emphasising the vital possibilities and open-ended spaces that might be opened - both in artistic sense and ontologically - once the conceptual barriers associated with binary thinking is evaded. Through her entire oeuvre, which enacts a comprehensive corporeal respatialisation, Orlan might, in fact, be questioning the traditionally hierarchical and oppositional ways in which we think about ourselves and the world, and open pathways for envisioning non-dualistic forms of bodily space that are no longer based on binary divisions. Thus, she opens the

66 Gilles Deleuze, Difference and Repetition, trans. Paul Patton (NY: Columbia University Press, 1994), 41. 
ground for experimentation performed on the body and creation of previously unimagined forms of embodiment, provoking public debate about our bodies and their futures. Such provocations bring us back to what Orlan precisely wants her Carnal Art to do, to be a public site for debate. As it has been argued throughout this chapter, Orlan questions the binary modes of thinking and strives to move beyond the boundaries of accepted realities and spatialities towards the in-between spaces of potential connections and diverse possibilities. These intermezzos - spaces of bodily difference and encounter, instead of sameness and identity - are central to her whole body of work and perhaps also signal towards a future that evades more dualisms and more of the same.

\section{Bibliography}

Adams, Parveen. 'Operation Orlan.' The Emptiness of the Image:Psychoanalysis and Sexual Differences. London: Routledge, 1995.

Auslander, Philip. From Acting to Performance: Essays in Modernism and Postmodernism. London: Routledge, 1997.

Ayers, Robert. 'Serene and Happy and Distant: An Interview with Orlan.' Body Modification, edited by Mike Featherstone, 171-184. London: Sage, 2000.

Bogue, Ronald. Deleuze and Guattari. London and New York: Routledge, 1989.

Braidotti, Rosi. Metamorphoses: Towards a Materialist Theory of Becoming. Cambridge: Polity Press, 2002.

Braidotti, Rosi. 'Affirming The Affirmative: On Nomadic Affectivity.' Rhizomes 11/12 (2005/2006): np. Viewed on 15 January 2016. http://www.rhizomes.net/issue11/ braidotti.html.

Brand, Peg Zeglin. 'Bound to Beauty: An Interview with Orlan.' Beauty Matters, edited by Peg Zeglin Brand, 289-313. Bloomington: Indiana University Press, 2000.

Davis, Kathy. 'My Body is My Art”: Cosmetic Surgery as Feminist Utopia?' The European Journal of Women's Studies 4.1 (1997): 26-41.

De la Villa, Rocio. 'Orlan's Wardrobe.' Orlan + Davidelfin: Suture, Hybridisation, Recycling, edited by Rocio De la Villa and Pedro Alberto Cruz Sanchez, 15-42. NC: Murcia Cultural, 2009.

Deleuze, Gilles. Foucault. Translated by Sean Hand. Minneapolis: University of Minnesota Press, 1988.

Deleuze, Gilles. Difference and Repetition. Translated by Paul Patton. Columbia University Press, 1994.

Deleuze, Gilles and Félix Guittari. Anti-Oedipus: Capitalism and Schizophrenia. Translated by R. Hurley, M. Seem, and H.R. Lane. Minneapolis: University of Minnesota Press, 1983. 
Deleuze, Gilles and Félix Guittari. A Thousand Plateaus: Capitalism and Schizophrenia. Translated by B. Massumi. Minneapolis and London: University of Minnesota Press, 1987 .

Deleuze, Gilles and Claire Parnet. Dialogues. Translated by H. Tomlinson and B. Habberjam. London: The Athlone Press, 1987b.

Goodall, Jane. 'An Order of Pure Decision: Un-Natural Selection in the Work of Stelarc and Orlan.' Body Modification, edited by Mike Featherstone, 149-170. London: Sage, 2000.

Grosz, Elizabeth. Volatile Bodies: Toward a Corporeal Feminism. Bloomington: Indiana University Press, 1994.

Grosz, Elizabeth. Architecture from the Outside: Essays on Virtual and Real Space. Cambridge/Mass: MIT Press, 2001.

Hirschhorn, Michelle. 'Orlan: Artist in the Post-Human Age of Mechanical Reincarnation: Body as Ready (to be re-) Made.' Generations \& Geographies in the Visual Arts: Feminist Readings, edited by Griselda Pollock, 110-134. London: Routledge, 1996.

Ince, Kate. Orlan: Millennial Female. Oxford and New York: Berg Publishers, 2000.

Jones, Amelia. Body Art/Performing the Subject. Minneapolis: University of Minnesota Press, 1998.

O’Bryan, C. Jill. Carnal Art: Orlan's Refacing. Minneapolis: University of Minnesota Press, 2005.

Orlan. 'Intervention.' The Ends of Performance, edited by Peggy Phelan and Jill Lane, 315-327. New York and London: NYU Press, 1998.

Orlan. 'Harlequin Coat.' Sk-Interfaces: Exploding Borders - Creating Membranes in Art, Technology and Society, edited by Jens Hauser, 83-89. Liverpool: FACT and Liverpool University Press, 2008.

Orlan. 'Carnal Art Manifesto.' Accessed 18 February 2016. http://orlan.net.

Ruhs, August. 'Orlan Metamorphoser.' Body as Membrane nv (1996): 46.

Schultz-Touge, Christine. Orlan: Carnal Art. Paris: Flammarion, 2004.

Zimmermann, Anja. "Sorry for Having to Make You Suffer": Body, Spectator, and the Gaze in the Performances of Yves Klein, Gina Pane, and Orlan.' Discourse 24.3 (2002): 27-46. 